\title{
HYDRODYNAMIC AND BOUSSINESQ WAVE MODELING FOR THE N219 AMPHIBIOUS AIRCRAFT SEAPLANE DOCK DEVELOPMENT PLAN IN PANJANG ISLAND
}

\author{
Hanah Khoirunnisa ${ }^{1}$, Mardi Wibowo ${ }^{1}$, Wahyu Hendriyono ${ }^{1}$, Khusnul Setia Wardani ${ }^{2}$ \\ ${ }^{1}$ Center of Technology for Maritime Industrial Engineering, \\ ${ }^{2}$ Laboratory for Harbour Infrastructure and Coastal Dynamics Technology \\ Agency for the Assessment and Application of Technology \\ e-mail:hanah.khoirunnisa@bppt.go.id
}

\begin{abstract}
The flight test of N219 Amphibious aircraft will be targeted in 2023/2024 and it needs a seaplane dock. One of the potential locations for the seaplane dock is Panjang Island at Seribu Islands. This study aims to know the characteristic of hydrodynamic and wave conditions and to determine whether Panjang Island is suitable for the seaplane dock. This study uses a modeling method with MIKE 21 Flexible mesh (FM) Hydrodynamic-Spectral wave (HD-SW) module and MIKE 21 Boussinesq Wave (BW) module. The needed data are the bathymetry data were obtained from the Indonesian Navy Hydrographic and Oceanographic Center (Pushidrosal), tidal data, wave and wind data. The validation result between hydrodynamic modeling and Tidal model driver (TMD) is $92 \%$. Current velocity has a range of $0.018-0.199 \mathrm{~m} / \mathrm{s}$ during the west monsoon and $0.02-0.193 \mathrm{~m} / \mathrm{s}$ during the east monsoon. The 50-year return period modeling resulted the maximum wave height between 1.139 to $1.474 \mathrm{~m}$. Furthermore, the significant wave height has the range of 0.679 to 0.741 with a period of 13.45 seconds. In general, the current and wave conditions in Panjang Island are suitable for the construction of the seaplane dock, except that the dominant wave heights are still above the requirements.
\end{abstract}

Keywords: boussinesq wave; hydrodynamic modeling; spectral wave; N219A; seaplane dock

Received: 2021-04-05; Revised: 2021-07-10; Accepted: 2021-07-13

\section{INTRODUCTION}

Indonesia's geographic condition is an archipelago stretching $81,000 \mathrm{~km}$ long. It demands the development of fast transportation modes that can connect small islands and the existence of outer islands on the border of Indonesia effectively.

Based on Republic Indonesia's law no. 1 of 2009 concerning aviation, article 1 states that aviation is a unified system consisting of the use of airspace, aircraft, airports, air transportation, flight navigation, safety and security, the environment and other supporting facilities [1]. Development in small islands must be carried out in a sustainable manner with an approach that prioritizes ecological balance, economy and conservation so that it is hoped that there will be an acceleration of economic growth and problems of income distribution [2]. As stated in Law Number 1 of 2009 and Regulation of the Minister of Transportation Number 9 of 2016 that for connecting remote areas, underdeveloped areas, areas that have not been served by other modes of transportation and to encourage regional growth and development in order to achieve stability, defense and security, and state security, it is necessary to organize pioneering air transportation [1], [3].

The recent transportation to connect small islands, border water security, and post-aid natural disasters are by using ships or helicopters. Furthermore, the Agency for the Assessment and Application of Technology (BPPT) conducted research about designed headquarter ships to support the security of the outer islands for the sake of the sovereignty of the 
Republic of Indonesia, through rotational transportation of security officers/TNI [4].

Another idea for such transportation was the development of an amphibious aircraft. The Amphibious Aircraft Development Plan (N219A) is in line with the 2020-2024 National Medium Term Development Plan [5] and the 2015-2035 National Industrial Development Master Plan [6]. In 2023/2024, Indonesia will target to produce amphibious aircraft. The N219 Amphibious Aircraft is a development of the N219 aircraft which was designed as a multi-functional amphibious aircraft. Multi-function in this case can be used as a passenger and cargo aircraft, for military purposes, even as a disaster relief aircraft.

The seaplane dock is an important part of amphibious aircraft development, especially during the flight test phase. Therefore, we need a study related to the criteria and alternative locations for the construction seaplane dock of the N219 Amphibious aircraft. It needs specific conditions in the wave, current condition, bathymetry, and wind condition for their operational safety. Therefore, it requires hydrodynamic and waves modeling as structural design considerations.

Hydrodynamic modeling at the planned seaplane dock construction site is needed as input in planning and design. One of the potential alternative areas for a seaplane dock is Panjang Island - Seribu Islands. Therefore, this study and modeling were carried out based on existing secondary data. These secondary data were obtained and generated from competent institutions and valid models.

The tidal type in the waters of Seribu Islands is mixed mainly diurnal [7]. Another study analyzed tidal conditions on Kelapa Dua Island, Seribu Islands, where it was found that tides can affect conditions of salinity, temperature, and current velocity [8].

The current velocity has been modeled using MIKE $21 \mathrm{HD}$ SW around Tidung Island, Seribu Islands during the transitional season (MarchMay) [9]. This modeling produces a current velocity of $0.0341-0.277 \mathrm{~m} / \mathrm{s}$. [10] conducted hydrodynamic modelling around Pari Island using the baroclinic 3-dimensional numerical model of the Hamburg Shelf Ocean Model (HAMSOM). The driving force used in the HAMSOM model is the tidal force [10] - [13]. Hydrodynamic modeling in the Seribu Islands was also carried out by [14] around Semak Daun Lagoon using MIKE 21 with the results that the current velocity around the area is influenced by tides. Based on research conducted by [15], the ocean waves in Pari Island are classified as the smooth sea with the range of significant wave height is 0.16 to $0.51 \mathrm{~m}$ and it has the wave period range of 2 to 4 seconds.

The characteristics of wind and its relationship to erosion in the Seribu Islands have been examined by [16]. During the east monsoon, the wind conditions in Seribu Islands are persistent north-westward. Meanwhile, during the west monsoon, there are extreme conditions for wind speed. The hydrodynamic conditions in Jakarta Bay due to the influence of reclamation have been researched by [17]. The results of these studies indicate that the reclamation does not affect the surface current velocity.

Meanwhile, the Government of Indonesia has issued the Director-General of Civil Aviation Regulation No. SKEP/227/VIII / 2010 concerning Manual of Standard CASR Part 139 Vol III Seaplane Water base [18]. This regulation is one of the guidelines for choosing a seaplane dock location [18]. Another reference that can be used is Advisory Circular AC No: 150/595-1B Subject: Seaplane Bases, 8/31/2018 [19].

Based on [19], several things need to be considered in selecting the location of the water operating area for the seaplane dock, including current direction, current speed, water depth, wave direction, wave height, wind direction, and wind speed.

Panjang Island is one of the islands in the Seribu Islands of DKI Jakarta Province. The length island is about $1.7 \mathrm{~km}$ and less than 0.25 $\mathrm{km}$ wide. The hydrodynamic (HD), spectral wave (SW), and Boussinesq Wave (BW) condition around the Panjang Island will be carried out in this study using MIKE 21 software [20]. Figure 1 shows the location and coverage of this study area.

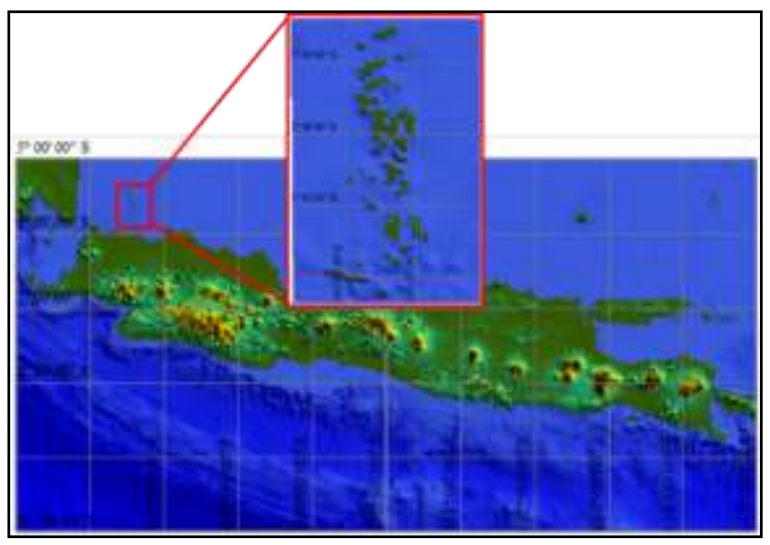

Figure 1. The domain of hydrodynamic modeling [21]. 
This hydrodynamic modeling aims to obtain the current and wave condition around Panjang Island, Seribu Islands. While BW modeling aims to determine the conditions of maximum wave height and significant wave height during the 50 year return period by using the MIKE 21 software module MIKE $21 \mathrm{BW}$ in the Seribu Islands for consideration of seaplane development based on N219A. The results of this modeling can be used to determine whether Panjang Island is suitable for the seaplane dock.

\section{DATA AND METHODS}

This research is conducted in the Laboratory for Harbour Infrastructure and Coastal Dynamics Technology (BTIPDP), BPPT.

The simulations used hydrodynamic and spectral wave (HD - SW) module and BW module of MIKE 21 software [20]. The flexible mesh is applied in the modeling domain by the amount of generated meshes of 8,174 mesh with a domain area of $31 \times 27 \mathrm{~km}$.

Meanwhile, the BW modeling uses a grid domain with a grid size of $5 \mathrm{~m} \times 5 \mathrm{~m}$ with a total grid of $1,001 \times 801$.

HD-SW modeling uses tidal data in each modeling boundary domain obtained from the Tide Model Driver (TMD) at intervals of one hour time [22]. The wind speed, wind direction, significant wave height, wave period, and wave direction data could be downloaded in the European Center for Medium-Range Weather Forecast (ECMWF) for 11 years (2009 - 2020) with a time interval of 3 hours and a resolution of $0.5^{\circ} \times 0.5^{\circ}[23]$ and bathymetry data obtained from Indonesian Navy Hydrographic and Oceanographic Center [24], The General Bathymetric Chart of the Oceans (GEBCO) [25] and BatNas [26] Figure 2. HD-SW modeling during the west monsoon has a modeling period from 5 December 2019 to 5 March 2020. Besides in the east monsoon, it has a time from 1 June 2020 to 1 September 2020.

The results of HD-SW modeling are used to know variations in current and wave conditions during a certain period (west \& east monsoon).

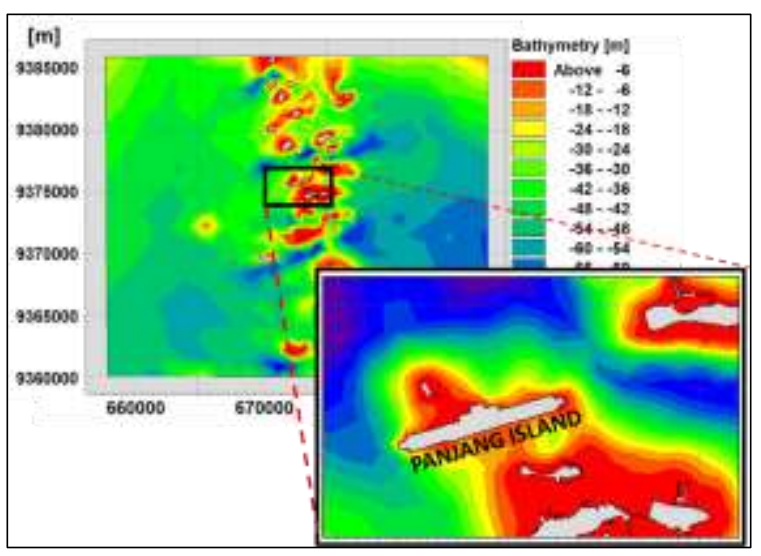

Figure 2. Bathymetry domain for hydrodynamic modeling and focused on Panjang Island.

BW modeling aims to obtain the maximum wave height and significant wave height conditions for the 50-year return period around Panjang Island. BW modeling was carried out for 15 minutes to obtain a stable condition for wave height around Panjang Island. Besides, the BW modeling includes bed resistance conditions with values ranging from $10-32 \mathrm{~m}^{1 / 3} / \mathrm{s}$ depending on the bathymetry.

The input scenarios used in BW modeling are as follows:

1. The dfsu file bathymetry domain modeling based on bathymetry and shoreline data that have been obtained from GEBCO and digitization of google earth.

2. The dfs2 files bathymetry around Panjang Island with a grid of $5 \mathrm{~m}$ and a grid number of $1,001 \times 801$, see Figure 3 .

3. The dfs2 file of manning data around Panjang Island with a $5 \mathrm{~m}$ grid. It used to have values of $32,20,10$, and $6 \mathrm{~m}^{1 / 3} / \mathrm{s}$ see Figure 4

4. The dfs 2 porosity file around Panjang Island with a $5 \mathrm{~m}$ grid, see Figure 5 .

5. The dfs2 sponge files around Panjang Island with a $5 \mathrm{~m}$ grid.

Wave input data in BW modeling is generated from wave tools in MIKE 21 Toolbox and resulted in the internal generation of the wave. It is calculated from significant wave height and significant wave periods at the 50-year return period. It has a value of $2.77 \mathrm{~m}$ and $13.45 \mathrm{~s}$. 


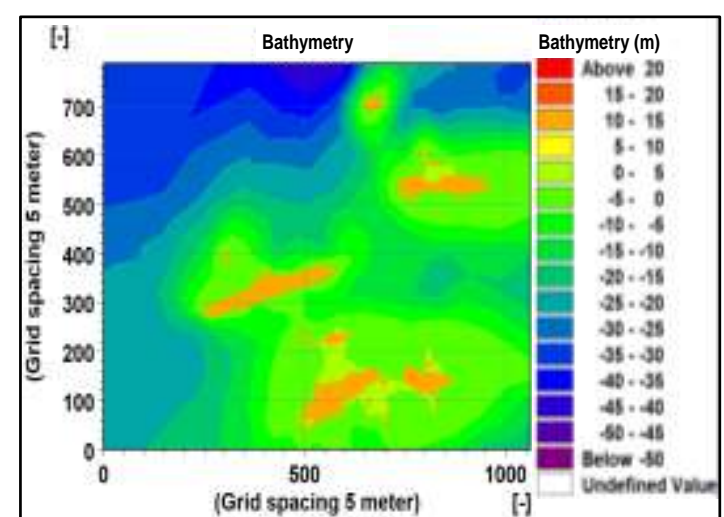

Figure 3. Bathymetry domain of BW modeling around Panjang Island.

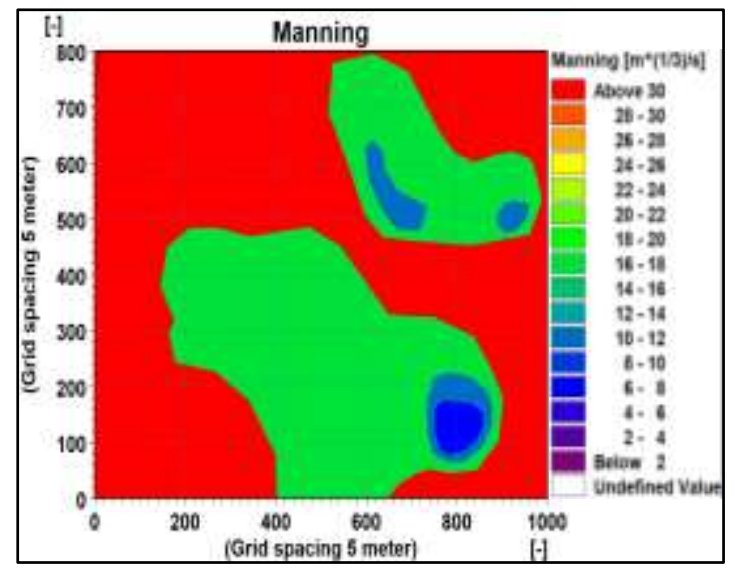

Figure 4. Manning map around Panjang Island.

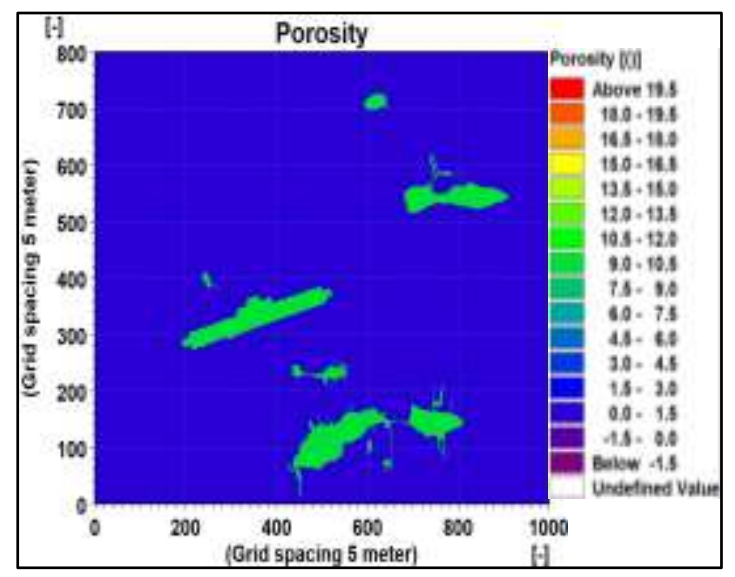

Figure 5. Porosity map around Panjang Island.

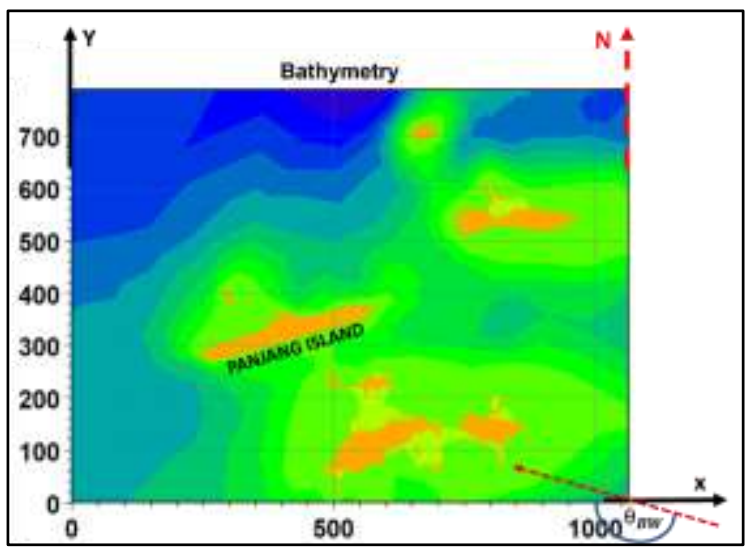

Figure 6. Illustration of determining the angle of incidence of waves at random wave generation input.

BW modeling is carried out using internal input wave generation with random wave type and angle of incidence $\left(\boldsymbol{\theta}_{\boldsymbol{B} W}\right) 170^{\circ}$ Figure 6 , and using the equation:

$$
\theta_{B W}=-\theta_{M E T}+\alpha_{O R I}+270
$$

with:

$\theta_{B W} \quad$ : angle of incidence of BW

$\theta_{M E T} \quad$ : angle of the origin

$\alpha_{O R I}:$ the difference between the north and the $y$-axis angle

The BW modeling aims to determine the conditions of maximum wave height and significant wave height during the 50-year return period. The result of this BW modeling is used as consideration for designing building structures according to the defined/planned lifetime.

The results of hydrodynamic modeling will be validated against tidal data from Tidal Model Driver (TMD) using the normalization root mean squared (NRMSD) formula, as follows:

$$
\begin{aligned}
& R M S D=\sqrt{\frac{\sum_{t=1}^{T}\left(x_{1, t}-x_{2, t}\right)^{2}}{T}} \\
& N R M S D=\frac{R M S D}{y_{\max }-y_{\min }}
\end{aligned}
$$




\section{RESULTS AND DISCUSSION}

\section{Hydrodynamic Modelling}

The surface elevation results from hydrodynamic modeling were validated using the tidal model of TMD and its NRMSD value of $92 \%$. The results of hydrodynamic modeling show that the maximum surface elevation is $0.496 \mathrm{~m}$ and a minimum of -0.524 from mean sea level (MSL) (in the west monsoon) and a maximum of $0.506 \mathrm{~m}$ and a minimum of -0.474 from MSL (at east monsoon) at the location of the seaplane dock development plan. Figure 7 and Figure 8 show the velocity and direction of currents around Panjang Island waters during the west and east monsoons. Current velocity at the planned seaplane dock construction site in both the west and east monsoons is relatively slow $(<0.19 \mathrm{~m} / \mathrm{s})$.

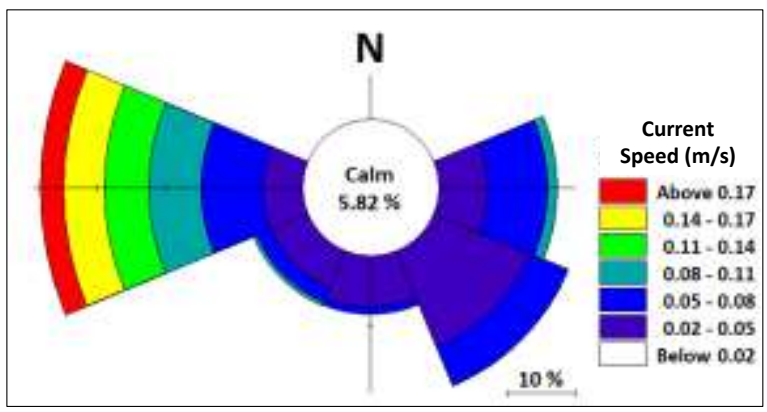

Figure 7. Current speed $(\mathrm{m} / \mathrm{s})$ and direction $(\operatorname{deg} N)$ around the seaplane dock location plan at western monsoon.

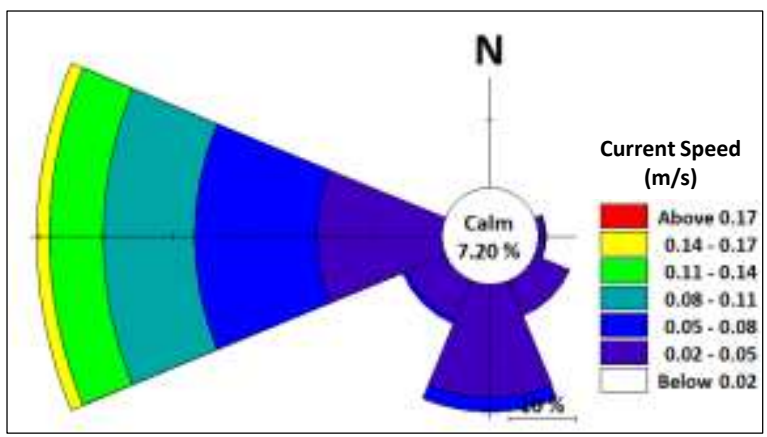

Figure 8. Current speed $(\mathrm{m} / \mathrm{s})$ and direction $(\operatorname{deg} N)$ around the seaplane dock location plan

In the west monsoon, the dominant current is westward directionally. Meanwhile, at the east monsoon, it is westward and southward directionally. The dominant current velocity is between $0.02-0.05 \mathrm{~m} / \mathrm{s}$.
Figure 9 is an example of a snapshot of the hydrodynamic modeling results in the west monsoon. This figure shows the condition of surface elevation, current velocity, and its direction in the west monsoon. In the spring conditions, the difference of the highest and lowest current velocities is quite large (0.018$0.199 \mathrm{~m} / \mathrm{s}$ ), on the other hand, when the tides are low in the neap condition $(0.008-0.144 \mathrm{~m} / \mathrm{s})$. The condition of the water level when it comes to high tide varies between -0.105 to $0.105 \mathrm{~m}$ and has a maximum current speed of $0.65 \mathrm{~m} / \mathrm{s}$. At maximum high tide conditions, the surface elevation ranges from $0.49 \mathrm{~m}-0.504 \mathrm{~m}$ and has a maximum current speed of $0.28 \mathrm{~m} / \mathrm{s}$. The water level when it comes to low tide is between $0.264-0.320 \mathrm{~m}$ and has a maximum current speed of $0.21 \mathrm{~m} / \mathrm{s}$ with a dominant speed of $0.06-0.15 \mathrm{~m} / \mathrm{s}$. During maximum low tide, the surface elevation ranges from -0.6 to $0.1 \mathrm{~m}$. The current direction at maximum low tide is dominantly eastward with a current speed of $<0.1 \mathrm{~m} / \mathrm{s}$.

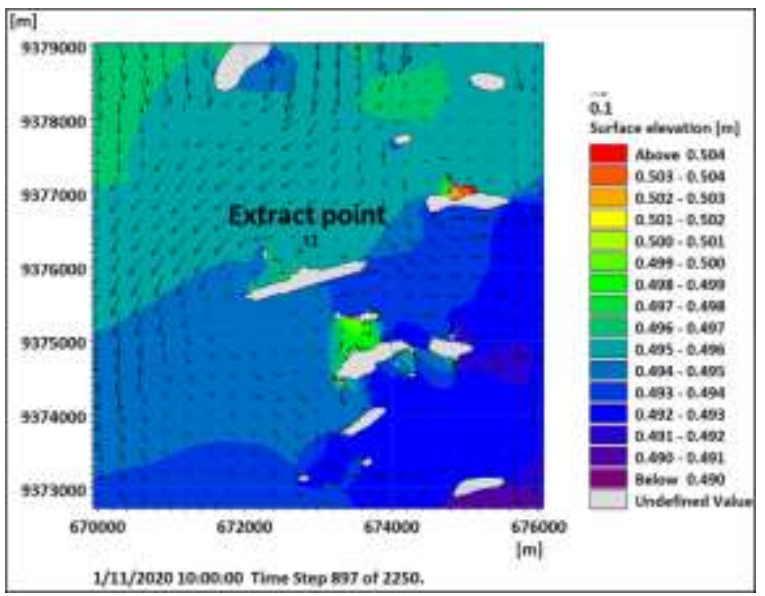

Figure 9. Snapshot of current velocity and surface elevation around Panjang Island during the west monsoon and its extract point.

Figure 10 shows the surface elevation conditions during the eastern monsoon. The current velocity is generally influenced by tides. During the spring condition, the current velocity is higher than in the neap condition. Its value has a range of 0.02 to $0.193 \mathrm{~m} / \mathrm{s}$, while the neap condition is 0.008 to $0.146 \mathrm{~m} / \mathrm{s}$. In the conditions leading to high tide, the water level has a range of -0.12 to $0.09 \mathrm{~m}$ and has a maximum current speed of $1.12 \mathrm{~m} / \mathrm{s}$ with a dominant speed of $<0.24$ $\mathrm{m} / \mathrm{s}$. At maximum tide conditions, the surface elevation ranges from 0.501 to $0.522 \mathrm{~m}$ and has a dominant current velocity to the south with a 
dominant current velocity $<0.08 \mathrm{~m} / \mathrm{s}$ with a maximum speed of $0.3 \mathrm{~m} / \mathrm{s}$. The surface elevation value when it comes to the low tide ranges from -0.48 to $0.08 \mathrm{~m}$ and has an eastward current velocity with a dominant speed $<0.1 \mathrm{~m} / \mathrm{s}$ and a maximum current velocity of $0.65 \mathrm{~m} / \mathrm{s}$. At the time of lowest tide, the surface elevation ranges from -0.48 to $0.08 \mathrm{~m}$ and has a current velocity dominantly northward with a current velocity $<0.08 \mathrm{~m} / \mathrm{s}$, and a maximum current speed of $0.44 \mathrm{~m} / \mathrm{s}$ which is in the northern part of the domain.

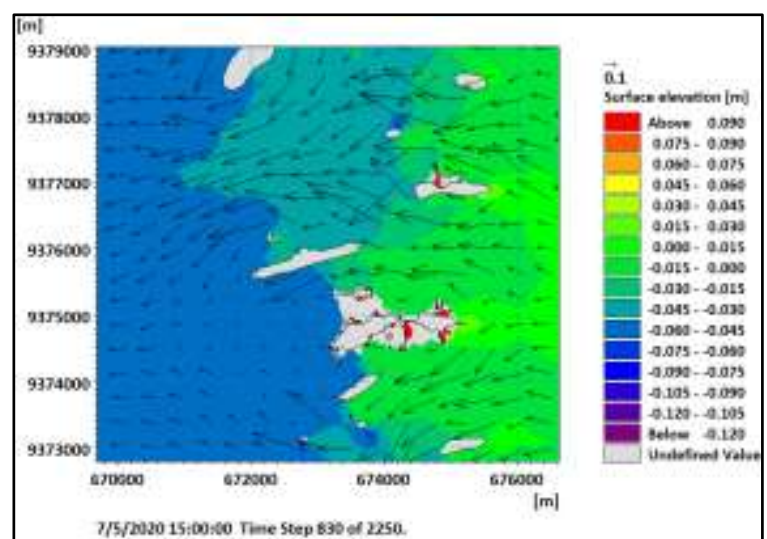

Figure 10. Snapshot of current velocity and surface elevation around Panjang Island during the east monsoon.

Based on bathymetry data, the water depth at the planned seaplane dock construction is less than $1.5 \mathrm{~m}$ from MSL. According to [18] and [27], the depth of the water measured at low water levels in the water runway should not be less than $1.8 \mathrm{~m}$ (6 ft.), dredging work may be needed.

Based on the hydrodynamic modeling, we know that the change of water level is $1.02 \mathrm{~m}$ (at west monsoon) and $0.98 \mathrm{~m}$ (at east monsoon). Generally, if the change in water levels exceeds 18 inches, it will be necessary to utilize floating structures or moderately inclined beaching accommodations to facilitate the handling of seaplanes at the shoreline or waterfront. Where water-level variations are more than 6 feet, special or extended developments to accommodate seaplanes must be made [27].

In general, currents at the seawater of Panjang Island meet the requirements for seaplane docks because their velocities are less than $0.5 \mathrm{~m} / \mathrm{s}$. According to [18] Director General of Civil Aviation Regulation No. SKEP/27/VIII/2010 concerning Manual of Standard CASR Part 139 Vol III Seaplane Water base, the current speed could not be more than $5.5 \mathrm{~km} / \mathrm{h}(1.53 \mathrm{~m} / \mathrm{s})$ [18]. Based on [27], a recommendation for the landing and take-off areas might be located where the currents are less than 3 knots $(1.54 \mathrm{~m} / \mathrm{s})$. Landing and take-off operations can be conducted in water currents over 6 knots but any taxiing operation between the sea lane (or operating water area) and the shoreline facilities will usually require the assistance of a surface craft. Currents over 3 knots or $1.54 \mathrm{~m} / \mathrm{s}$ usually cause some difficulty in handling seaplanes, particularly in slow taxiing mode while approaching piers, floating docks, or in beaching operations like ramps.

Figures 11 and 12 show the current velocity conditions and current direction which are depicted on a time series graph during the west monsoons and the east monsoons. During the west monsoon, the current velocity has a maximum value of $>0.2 \mathrm{~m} / \mathrm{s}$. Meanwhile, during the east monsoon, the current velocity has a maximum value of $0.15 \mathrm{~m} / \mathrm{s}$.

\section{Spectral Wave Modelling}

Spectral wave modeling on Panjang Island was carried out using MIKE 21 HD - SW software. This model is a wind-generated wave. The wind speed, wave height and period from ECMWF are used as generating forces in spectral wave modeling. In addition, the water level from HD simulation is also used in the input spectral wave modeling [28].

Figure 13 shows a snapshot of significant wave height both at west monsoon and east monsoon. Base on this model we know that at the west monsoon the wave dominant from the north direction with wave height $0.14-0.21 \mathrm{~m}$ and maximum wave height $0.409 \mathrm{~m}$. At the East monsoon, the wave is dominant from the northeast with wave height $0.12-0.18 \mathrm{~m}$ and maximum wave height $0.248 \mathrm{~m}$. The wave period condition on the northern location of Panjang Island has a range from 2.28 to 4.89 seconds in the west monsoon and 2.89 to 4.58 seconds in the east monsoon.

The most desirable conditions exist where the surface of the water is moderately disturbed, having ripples or waves approximately 3 to 6 inches in height. The average light seaplane (3,000 pounds or less), equipped with twin floats, can generally be operated safely in seas running to about 15 inches measured from crest to trough, while 18-inch seas will restrict normal safe operations of these seaplanes. Larger floatequipped or hull-type aircraft ranging in weight from 3,000 to 15,000 pounds can generally be 
operated safely in seas running as high as 2 feet measured from crest to trough [27].
Figure 13. Snapshot of spectral wave modeling results in the west monsoon (top) and the east

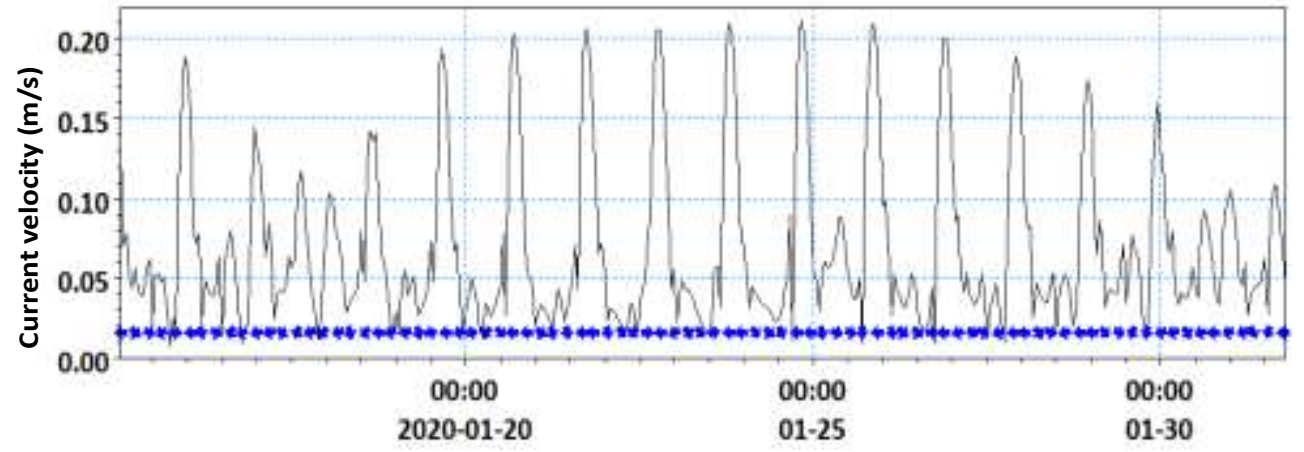

Figure 11. The time series graph of current velocity (black line) and direction

(blue arrow) in January (western monsoon).

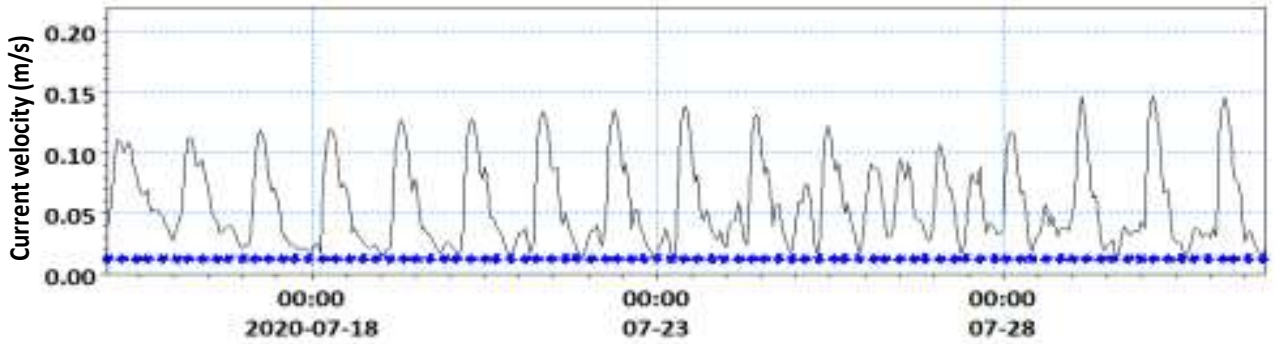

Figure 12. The time series graph of current velocity (black line) and direction (blue arrow) in July (eastern monsoon).

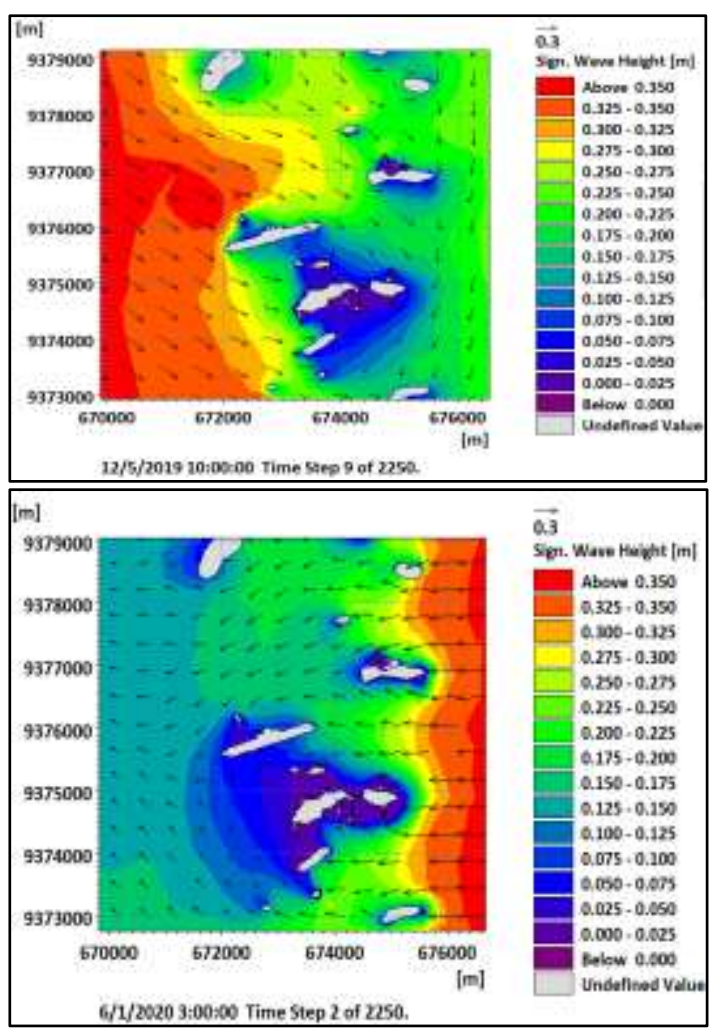

monsoon (bottom).

\section{Boussinesq Wave Modelling}

Figure 14 shows the condition of the instantaneous surface elevation at the 50-year return period, where the value is obtained based on the input of significant wave height and period calculated from the 50-year return period. The input of regular wave is placed on the eastern boundary of the domain, and it propagates westward and north-westward or $170^{\circ} \mathrm{BW}$ angle due to the direction of the dominant wave comes from the east and southeast. 


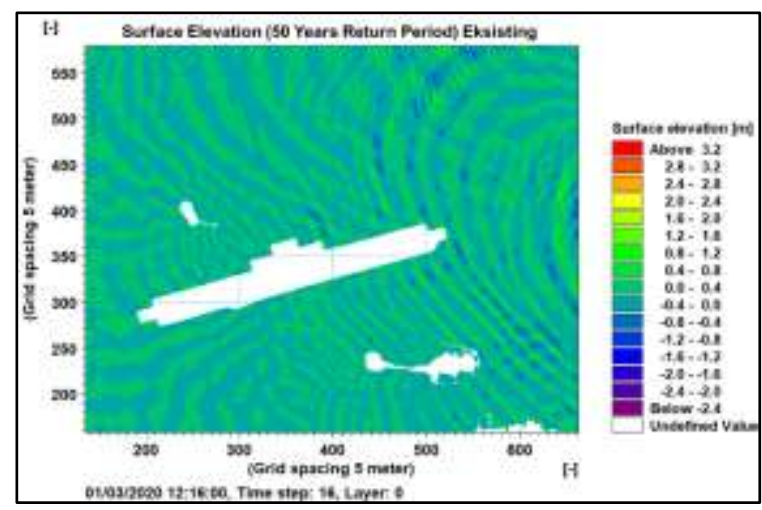

Figure 14. The surface elevation results of BW modeling for the existing scenario around

Panjang Island with a 50 year return period.

The 50-year return period surface elevation at the northern point of Panjang Island has a value of $0.05 \mathrm{~m}$. Based on [27], the surface elevation value around Panjang Island is safe to be used as a seaplane dock construction site due to it is less than the maximum water level limit. The surface elevation of the 50-year return period on Panjang Island varies from -2.4 to $3.2 \mathrm{~m}$. In addition, based on BW modeling, the maximum and significant wave height conditions around Panjang Island for the 50-year return period Figure 15. Based on the figure, the wave height propagates to the west and northwest with $170^{\circ}$ BW angle. The value of the wave height based on Figure 15 varies with a range of 0 to $4.4 \mathrm{~m}$.

Significant and maximum wave height around Panjang Island is extracted with extract

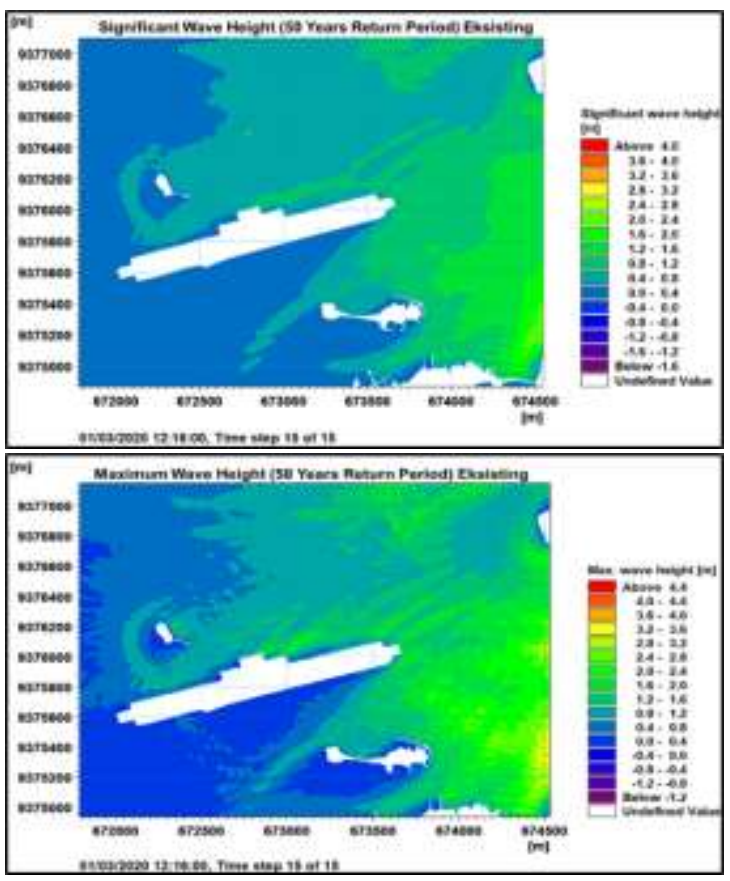

points as shown in Figure 16 and Table 1, as well as extract results as shown in Table 2. The 50year return wave height at the northern point of Panjang Island has a value of 0.773 and $1.26 \mathrm{~m}$ for the significant and maximum wave height Figure 15. This value exceeds the safe limit of wave height for the construction of a seaplane dock. Based on [27] the maximum wave height limit value is 2 feet or $0.6 \mathrm{~m}$. Furthermore, if the construction of the seaplane dock is planned for the next 50 years, the condition of the wave height must be considered.

Figure 15. Results of significant wave height (top) and maximum wave height (bottom) of BW modeling around Panjang Island with a 50-year return period.

To quantitatively know the wave height around Panjang Island, it is necessary to extract at the focus location. Figure 16 shows the location of the extract points from the BW modeling results and Table 1 shows the depth conditions at each point around Panjang Island, where point 4 has the deepest bathymetric conditions compared to other points, namely $23.07 \mathrm{~m}$.

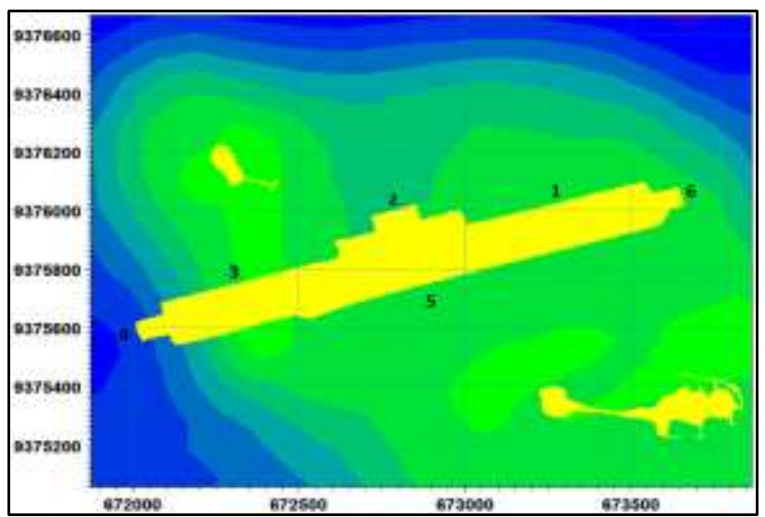

Figure 16. Locations and extract points for the existing BW scenario modeling around Panjang Island.

Table 1. The depth of locations 1 to 6 .

\begin{tabular}{cccc}
\hline \multirow{2}{*}{ Point } & \multicolumn{2}{c}{ UTM 48S } & Depth \\
& Easting & Northing & (m) \\
\hline 1 & 673222 & 9376106 & -6.20 \\
2 & 672768 & 9376084 & -9.90 \\
3 & 672336 & 9375859 & -3.90 \\
4 & 671943 & 9375579 & -23.07 \\
5 & 672914 & 9375708 & -5.34 \\
6 & 673699 & 9376106 & -6.53 \\
\hline
\end{tabular}


Table 2. Significant wave heights and maximum wave heights with a 50-year return period.

\begin{tabular}{ccc}
\hline & \multicolumn{2}{c}{ Existing } \\
\cline { 2 - 3 } Point & $\begin{array}{c}\text { Maximum wave } \\
\text { height (m) }\end{array}$ & $\begin{array}{c}\text { Significant } \\
\text { wave height }(\mathbf{m})\end{array}$ \\
\hline 1 & 1.139 & 0.679 \\
2 & 1.229 & 0.773 \\
3 & 1.474 & 0.741 \\
4 & 0.286 & 0.133 \\
5 & 0.248 & 0.135 \\
6 & 2.088 & 1.269 \\
\hline
\end{tabular}

Table 2 shows the comparison of the conditions of significant wave height and maximum wave height from BW modeling at locations $1-6$ around Panjang Island on the 50 year return period. Location 6 has the highest significant wave height and maximum wave height, namely 1.269 and $2.088 \mathrm{~m}$. Meanwhile, between points 1,2 , and 3 , the highest maximum wave height value occurs at point 3 with a wave height of $1.474 \mathrm{~m}$.

\section{CONCLUSION}

The validation result of the surface elevation between the modeling and the tidal data from the TMD reached more than $92 \%$. The result of hydrodynamic modeling shows that the change of water level is $1.02 \mathrm{~m}$ (at west monsoon) and 0.98 $\mathrm{m}$ (at east monsoon), which exceeds a general rule. The value of the current speed of the HD modeling result around Panjang Island is relatively slow $(<0.19 \mathrm{~m} / \mathrm{s})$. It meets the requirements for seaplane docks. The dominant current is west and east directionally. Generally, the wave height in the west monsoon is dominantly from the north and northeast with a dominant wave height of $0.21 \mathrm{~m}$ and a maximum significant wave height of $0.409 \mathrm{~m}$. This needs to be considered because it exceeds the requirements. In a 50-year return period, the highest significant wave height is $1.269 \mathrm{~m}$, and the maximum wave height is $2.088 \mathrm{~m}$. So, if a seaplane dock is to be built with a design lifetime of 50 years, it must pay attention to the wave height.

\section{AUTHOR INFORMATION}

\section{Corresponding Authors}

Email: hanah.khoirunnisa@bppt.go.id

\section{Author Contributions}

In this study, HK and MW are the main contributors. The others are supporting contributors. All authors reviewed this manuscript.

\section{ACKNOWLEDGMENTS}

This paper is part of an ongoing research project with title Pengembangan Pesawat N219A, Kriteria Penentuan Lokasi Seaplane Dock (AMPHI-09). We would like to thank the management of BTIPDP-BPPT, Ministry of Research and Technology/National Research and Innovation Agency and LPDP for supporting this research project.

\section{REFERENCES}

[1] The Republic of Indonesia's Law Number 1 of 2009 on Aviation.

[2] R. F. Suryawan, M. Fatchoelqorib, Penerbangan Perintis dalam Mengembangkan Perekonomian di Pulau Karimunjawa. Jurnal Manajemen Transportasi \& Logistik. 2018, 5(2), pp. 161168.

[3] Regulation of the Minister of Transportation Number 9 of 2016.

[4] S. Samudro and A. Kadir, Characteristics design of Headquarters ship for border Protection Operation and Support to postNatural disaster Management in The Outlying Islands Community. Majalah IImiah Pengkajian Industri, 2016, 10(3), pp. 201210.

[5] Pemerintah Republik Indonesia, 2015, Rencana Pembangunan Jangka Menengah Nasional (RPJMN) 2015-2019.

[6] Pemerintah Republik Indonesia, 2015, Rencana Induk Pembangunan Industri Nasional (RIPIN) 2015-2035.

[7] E. Mustikasari and A. Rustam, Karakteristik Fisis Air Laut dan Dinamika Perairan Kepulauan Seribu, Jurnal Riset Jakarta, 2019, 12(2).

[8] M. Yudhantoko, G. Handoyo and M. Zainuri, Karakteristik dan Peramalan Pasang Surut di Pulau Kelapa Dua, Kabupaten Kepulauan Seribu, Journal of Oceanography, 2016, 5(3), pp. 368-377.

[9] G. M. Yogaswara, E. Indrayanti, and H. Setiyono, Pola arus permukaan di Perairan Pulau Tidung, Kepulauan Seribu, Provinsi DKI Jakarta pada Musim Peralihan (Maret- 
Mei), Journal of Oceanography, 2016, 5(2), pp. 227-233.

[10] M. R. Putri, A. Setiawan, T. Sari, B. Mayer, and T. Pohlmann, Trajectory Model for Identification of Oil Spill Around the Coast of Pari Island, Seribu Islands, North Jakarta, Jurnal IImu dan Teknologi Kelautan Tropis, 2017, 9(2), pp. 657-664.

[11] M. R. Putri, A. Setiawan, T. Pohlmann, B. Mayer and M. Gade, The assessment of oil pollution in Seribu Islands based on remote sensing and numerical models, In Proc. Living Planet Symp. 2016, Prague, Czech Republic, 3-16 May 2016.

[12] A. Setiawan, M. R. Putri, M. Gade, T. Pohlmann and B. Mayer, Combining ocean numerical model and SAR imagery to investigate the occurrence of oil pollution, a case study for the Java Sea. In IOP Conference Series: Earth and Environmental Science, 2017, 54(1), p. 012080, IOP Publishing.

[13] M. Gade, B. Mayer, C. Meier, T. Pohlmann, M. Putri, and A. Setiawan, Oil Pollution in Indonesian Waters: Combining Statistical Analyses of ENVISAT ASAR and Sentinel-1A C-SAR Data with Numerical Tracer Modeling, International Archives of the Photogrammetry, Remote Sensing \& Spatial Information Sciences, 2017, 42.

[14] Saenuddin, I. W. Nurjaya, D. G. Bengen, T. Prartono and I. Efendi, Hydrodynamics modelling with MIKE system in the Semak Daun Lagoon, Seribu Islands Indonesia. In IOP Conference Series: Earth and Environmental Science, 2020, 429(1), p. 012010, IOP Publishing.

[15] A. Vidura, I. W. Nurjaya, M. Iqbal and I. Jaya, Ocean wave measurement and wave energy calculation using an overtopping power plant scheme, In IOP Conference Series: Earth and Environmental Science, 2020, 429(1), p. 012047, IOP Publishing.

[16] Poerbandono, Wind characteristics and the associated risk of erosion in Seribu Islands patch reef complexes, Java Sea, Indonesia. In AIP Conference Proceedings, 2016, 1730(1), pp. 080001, AIP Publishing LLC.
[17] Y. N. Ihsan, Marine macro debris transport based on hydrodynamic model before and after reclamation in Jakarta Bay, Indonesia, Malaysian Journal of Applied Sciences, 2020, 5(2), pp. 100-111.

[18] Director General of Civil Aviation, 2010, PeraturanDirektur Jenderal Perhubungan Udara No. SKEP/227/VIII/2010 tentang Persyaratan Standar Teknis dan Operasional Peraturan Keselamatan Penerbangan Sipil Bagian 139 (Manual of Standard CASR part 139 Volume III Bandar Udara Perairan (Water Base), Kementerian Perhubungan.

[19] Federal Aviation Administration, 2018 Advisory Circular AC No.: 150/595-1B Subject: Seaplane Bases, 8/31/2018, US Department of Transportation.

[20] DHI, General MIKE ZERO, Pre-processing and Post Processing Vol. 1 User Guide, 2017.

[21] Google Earth, 2020.

[22] L. Padman and S. Erofeeva, Tide Model Driver (TMD) Manual, Earth and Space research, 2005.

[23] Copernicus Climate Change Service (C3S), ERA5: Fifth generation of ECMWF atmospheric reanalyses of the global climate. Copernicus Climate Change Service Climate Data Store (CDS), https://cds.climate.copernicus.eu/cdsapp\#!/h ome, 2018.

[24] DISHIDROS, Peta Laut Lembar Pulau Jukung Hingga Pulau Peniki Skala 1:50.000, Dinas Hidro-oseanografi-TNI AL, 1986.

[25] Gebco, 2021 https://www.gebco.net/data_and_products/g ridded_bathymetry_data/

[26] International Civil Aviation Organization, 2018, Asia Pacific Regional Guidance a Requirements for the Design and Operations of Water Aerodromes for Seaplane Operations, ICAO Asia and Pacific, Bangkok.

[27] DHI, MIKE 21 Spectral Wave Module, Scientific Documentation, 2017. 